\title{
IT-Based Technical Change and Job Instability*
}

\author{
Luc Behaghel \\ Paris School of Economics-INRA, FR-75014 Paris, France \\ luc.behaghel@ens.fr
}

\section{Julie Moschion}

University of Melbourne, Carlton, VIC 3053, Australia

moschion@unimelb.edu.au

\begin{abstract}
We investigate the impact of IT diffusion on the stability of employment. We document the evolution of different components of job instability over a panel of 348 cities in France, from the mid-1970s to the early 2000s. The evidence goes against the view that the diffusion of IT has spurred job instability. Yet, analysing long-term differences in the occupational structure, we find that IT diffusion has increased the share of high-skill occupations at the expense of low-skill occupations. This is consistent with French firms' reliance on their internal labour market to meet the new skill requirements associated with IT diffusion.
\end{abstract}

Keywords: Internal labour markets; job security; labour turnover; skill bias

JEL classification: $J 23 ; J 24 ; \quad J 41$

\section{Introduction}

Among the questions IT-based technical change raises among labour economists, one remains unanswered: to what extent has the diffusion of IT over the past decades modified the stability and the security of employment relationships? This question is relevant for many developed countries who are confronted with increases in involuntary job losses. Yet, the theoretical and empirical evidence on the role of IT is mixed (Mincer, 1989; Givord and Maurin, 2004; Neumark and Reed, 2004).

Several theoretical arguments predict that a rapid diffusion of IT should result in higher job instability. In Schumpeterian models, IT-based change, just like any other form of technical change, goes through a creative destruction process. The reallocation of workers across sectors or firms is

\footnotetext{
${ }^{*}$ We thank David Blau, Clement de Chaisemartin, Eve Caroli, and John Van Reenen for their insights; Maria-Eugenia Baez for excellent research assistance; Alexandre Kych at Centre Maurice Halbwachs for his help with the data; and the French Agence Nationale de la Recherche for financial support (grant number ANR-08-JCJC-0067-01).
} 
part of that process. In a frictionless labour market, this can simply result in more frequent job-to-job transitions; however in the presence of matching frictions, it might also create job insecurity, characterized by transitions from employment to non-employment ${ }^{1}$ This first argument is not specific to IT. A second argument is related to the role of IT in the "new economy", where firms create more value by the rapid introduction of new products and services, rather than by the continuous improvement of production processes. The perpetual recomposition of the firms' workforce is part of this post-Fordist model, as a way to introduce new talent and to develop creative approaches (Reich, 2001). IT diffusion can facilitate this turnover by allowing firms to codify their processes, making it easier for new workers to adapt quickly, and limiting the knowledge loss associated with the exit of more experienced workers (Caroli, 2007).

Yet, there are also theoretical reasons to believe that stable employment relationships are compatible with IT diffusion, especially in the longer run. When adjustments to the new technology have taken place, the new steady state (with IT) does not necessarily imply more instability. As argued by Mincer (1989), the best long-run response to technical change and the need for new skills might well be on-the-job training rather than costly worker flows. This leads to greater attachment of workers to firms (i.e., to lesser job mobility). Overall, human capital adjustments required by the development of IT "may first be obtained by hiring policies, and later by training as the processes become more routinized. If so, effects on labor mobility are also different in their time sequence" (Mincer, 1989).

In this paper, we provide empirical evidence on the impact of IT diffusion on the stability of employment relationships in France, from the mid-1970s to the early 2000s. France witnessed a sizable increase in job insecurity over the period: transitions to non-employment and transitions to unemployment increased by a factor of 1.5 to 2 , which makes it an interesting case to study. In the first part of the paper, we analyse the diffusion of PCs and the evolution of job instability over a panel of about 300 local labour markets ("cities"). Consistent with models of endogenous technology adoption, we find that workers in cities with higher education levels adopt IT faster (even after controlling for their own education level). However, they do not experience faster increase in job instability; more specifically, job-to- job transitions seem unaffected, while the diffusion of IT tends to reduce

\footnotetext{
${ }^{1}$ In keeping with the literature, we define job instability as the sum of voluntary and involuntary job exits, and define job insecurity as involuntary worker flows only, which we characterize through transitions from employment to non-employment (Gottschalk and Moffitt, 1999).
} 
transitions to non-employment. Overall, the evidence goes against the view that the diffusion of IT has spurred job instability. ${ }^{2}$

In addition, analysing long-term differences in the occupational structure across cities, we find that IT diffusion has increased the share of highskill occupations at the expense of low-skill occupations. Although the diffusion of IT leads to an upgrading of the occupational structure, it does not increase worker flows into and out of the firm. Overall, the findings are consistent with the view that French firms rely on their internal labour market to meet the new skill requirements associated with IT diffusion, as suggested by Behaghel et al. (2012).

Differences in skilled labour endowments across cities constitute an unusual source of variation to study the impact of IT on employment relationships. ${ }^{3}$ Other papers have used comparisons across industries (Givord and Maurin, 2004; Neumark and Reed, 2004) or across firms (Bauer and Bender, 2004; Behaghel et al., 2012), yielding quite contrasted results. ${ }^{4}$ Caselli (1999) and Acemoglu (2007) pursued a tradition in the economic history literature (Habakkuk, 1962; Goldin and Sokoloff, 1984), stressing the endogeneity of IT adoption and, more particularly, the role of initial factor endowments. Such models have been extended and applied to cities by Beaudry et al. (2010), who show that the adoption of PCs across US cities is significantly driven by the initial skill endowment. We find similar results for France: a worker located in a city with an initial high supply of skills tends to adopt IT faster. We discuss the conditions under which these local patterns in IT adoption are exogenous to the evolution of employment stability, and can be used to estimate a causal, aggregate impact

\footnotetext{
${ }^{2}$ Several other factors have been suggested as explanations for the increase in job instability observed in France, including the macroeconomic environment (in particular, the recession of 1993) and changes in employment protection laws, which were relaxed in 1986 before becoming more restrictive again after 1990 (Givord and Maurin, 2004).

3 An exception is Neumark and Reed (2004), who (among other things) investigate the prevalence of contingent and alternative employment relationships in high-tech cities.

${ }^{4}$ Neumark and Reed (2004) have contrasted results for the US. They find a significantly greater use of contingent and "alternative" employment relationships in jobs located in cities classified as high-tech. They also use cross-industry variations, with differing results: they find a greater use of contingent and alternative employment relationships in fast-growing industries, but a lesser use of these types of contracts in high-tech industries. Givord and Maurin (2004) study the evolution of involuntary job loss in France between 1982 and 2002 across industries, with the French LFS. They conclude that technological change contributes to increasing job insecurity. Bauer and Bender (2004) find that new technologies increase churning rates for skilled and unskilled workers. However, Behaghel et al. (2012) find that, although the introduction of new IT is associated with an upward shift of the occupational structure within firms, about two-thirds of this effect occurs through promotion rather than through the entry and exit of workers; moreover, IT adoption is not associated with excess turnover. They argue that this is consistent with the large diffusion of internal labour markets in France, whereas occupational labour markets are dominant in Germany (Marsden, 1999).
} 
of IT diffusion on employment stability. We check that the results are robust to controlling for alternative channels through which the initial skill endowment might affect the evolution of the local labour market.

In Section II, we provide some theoretical background. In Section III, we present the data and display descriptive evidence. In Section IV, we show the impact of IT diffusion on labour market transitions and on the occupational structure. In Section V, we offer some concluding comments.

\section{Theoretical Background}

In this section, we discuss the theoretical background for the two steps of our empirical analysis: why should the local supply of skilled labour affect the adoption of new IT-based technologies, and why should this, in turn, make employment relationships less stable?

As mentioned in the introduction, there is now a long-standing theoretical (and empirical) literature on endogenous technology adoption, according to which the pace and extent of technology adoption reflects principles of comparative advantage. Models of endogenous technology adoption have been developed in particular by Basu and Weil (1998), Zeira (1998), and Caselli (1999); a recent synthesis can be found in Beaudry et al. (2010). New technologies, such as the recent information and communication technologies associated with PCs, are adopted only in environments in which complementary factors, such as skilled labour, are abundant and therefore cheap. The neoclassical model of "technological revolution" developed by Beaudry et al. (2010) thus predicts that the probability that a worker uses a PC at work today is positively related to the abundance of educated workers in their city on the cusp of the PC era, even after controlling for the worker's individual education. This is the first prediction we test.

The second step of our analysis asks whether the adoption of IT leads to increased job instability or insecurity. Although such a phenomenon is frequently hypothesized, theoretical work on the actual mechanisms is limited. ${ }^{5}$ It is useful to distinguish the long-run perspective from the analysis of the transition period - that is, the "technical revolution" studied by Beaudry et al. (2010), which spans the period from 1980 to 2000 in their empirical analysis. During the transition period, firms gradually migrate to the new technology, and this is likely to increase the pace of job destruction, reducing job stability and security. In the long run, however, it is less clear whether one should expect more or less job stability in the "new economy" compared to the old one. Caroli (2007) argues that the codification

\footnotetext{
${ }^{5}$ See, for instance, the Business and Industry Advisory Committee to the OECD, quoted by Neumark and Reed (2004): "In the new economy, the employer/employee employment relationship has been turned upside down. Employees no longer stay with their company for their entire career."
} 
enabled by IT makes it possible to embody knowledge in firms themselves, lowering the relative cost of human resource management strategies based on external labour flexibility. However, other effects might be at play at the workplace, firm, or city level. Effects at the workplace level take place when a worker starts using IT. This should directly increase the worker's own productivity; whether it increases the probability of staying in the firm depends on how the outside options of the worker and the firm evolve. Moreover, the effect on productivity is partly endogenous, as it depends on whether and how the worker is trained to use the technology. A second type of effect is driven by the diffusion of IT in the firm (or more broadly in the city), independently from the adoption by the worker. There might be a positive impact of IT on all production factors (e.g., more efficient processes). There might also be complementarity or substitutability effects - one important hypothesis in the literature is that IT will tend to substitute for unskilled labour as it is concentrated in routine tasks. Overall, as argued by Mincer (1989), the long-run impact of IT adoption on job stability depends on firms' and workers' adaptation strategies, which in turn likely reflect the multiple factors that drive the relative costs of external and internal adjustments of the workforce (cost of training workers, costs associated with labour market protection, etc.).

Overall, theory clearly predicts a positive impact of skilled labour endowments on the adoption of IT at the local labour market. Predictions on the consequences for job stability are less clear-cut and should depend, among other things, on how firms adjust their human resource strategies; this is the main focus of our empirical analysis.

\section{Data and Descriptive Evidence}

Did cities with a more educated workforce adopt computers faster? Did the same cities witness a larger increase in job instability? In this section, we describe the data used to answer these questions, and provide some preliminary descriptive evidence.

Our test of the impact of local skill endowment requires data at the city level over a sufficient time span. We created a database at the level of the zones d'emploi (employment areas). The 348 zones d'emploi constitute a partition of the French territory; they were delimited by the French statistical institute (INSEE) and the Ministry of Labour on the basis of commuting data from the 1990 population census; we use this partition throughout the period. The working-age population of a given zone d'emploi can be thought of as the potential labour supply faced by local firms. In what follows, we use the term "city" for zone d'emploi, although some of these local labour markets are smaller and less urban than the word might connote. 


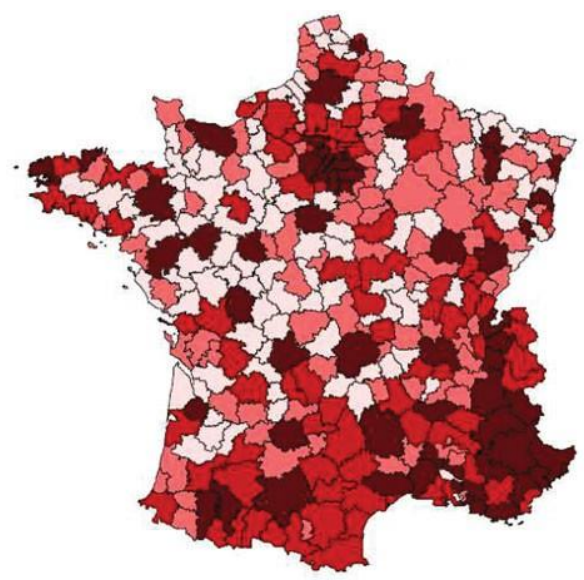

\section{SHARE34}

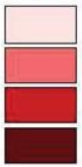

$0.07-0.1$

$0.1-0.12$

$0.12-0.15$

$0.15-0.36$
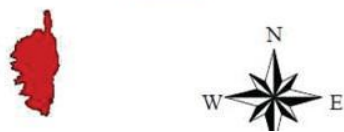

Fig. 1. Share of population with high school and higher educational attainment in 1975

Measures of the initial skill endowment come from the 1975 population census, through our access to tabulations from the complete data. As a measure of the initial skill endowment for a given city, $E d u c_{c 0}$, we use the share of the working-age population (aged 20 to 59) holding a high-school or higher degree. Variations in $E d u c_{c 0}$ are substantial: the (unweighted) mean across cities is 12.9 percent, with a standard deviation of 4.5 percent. The gap between the ninth and the first deciles is about 10 percentage points $(\mathrm{pp})(=18.6-8.7)$. As shown in Figure 1, more educated workers are concentrated in the South and the greater Paris area. Spatial correlations are strong (22 regional dummies explain 27 percent of the variance over the 348 cities). Moreover, differences in skill endowment are correlated with differences in population density (see Figure A1 in the Online Appendix). However, the correlation is far from perfect: for instance, although the North is densely populated, its population has relatively low educational attainment. Overall, the correlation coefficient between initial skill endowment and population density in 1975 is 0.41. Another feature of the data is the remarkable stability of endowment differences over time, as shown by comparing the maps in 1975 and 1999 (Figure A2 in the Online Appendix). The correlation coefficient between skill endowments at these two dates is as high as $0.93 .{ }^{6}$ Overall, there is a strong and stable

\footnotetext{
${ }^{6}$ The dispersion in skill endowments across regions is also similar for the share of the population with at least some college education (in 1975, the correlation coefficient between the share of the working-age population holding a high-school degree and those with college education is 0.98). As a result, our results are qualitatively similar if we use the college share in 1975 as our measure of initial skill endowment (see Table A2, Columns 3 and 6).
} 
dispersion in skill endowment over the French territory. Only part of it can be explained by the presence of cities and variation in population density. A likely hypothesis is that, similar to the US experience (Moretti, 2004), a significant determinant of these local differences has to do with the expansion of education in France in the late 19th and early 20th centuries.

Consistent series data on technology usage at the local level are rare in France. Firm surveys asking for information on software and hardware investments only started in the late 1990s, and often have data at the firm rather than the plant level, making it hard to analyse geographical repartitions. We therefore rely on supplements to the French Labour Force Survey (Enquete Emploi, hereafter called the LFS) in 1987, 1991, 1993, and 1998. These supplements ask workers detailed questions on their working conditions and the tools they use at work. Given our focus on IT, we construct two main indicators, one for the use of a PC at work (from 1987 to 1998), and the other for the use of the Internet (for 1998).

We rely on the 1975 to 2002 issues of the French LFS to compute yearto-year transition rates on the labour market. Over that period, the French LFS takes place each year in March as a three-year rotating panel with a $1 / 300$ sampling rate. ${ }^{7}$ Following the literature, we compute indicators for job instability and job insecurity based on transition rates out of a given job. Specifically, for job insecurity, we consider transitions from employment to non-employment based on transitions between year $t$ and $t+1$ among all wage earners aged 20 to 59. This indicator includes both transitions to unemployment and transitions out of the labour force; ${ }^{8}$ the key reason for including transitions out of the labour force is the prevalence of early retirement schemes for workers above 55 . Workers in early retirement will mostly declare themselves as out of the labour force (although some of them are technically receiving unemployment benefits). Firms have widely used early retirement schemes as a less painful way to adjust their workforce, often leaving workers with no better choices; it is therefore warranted to include these forced transitions in the job insecurity indicator. ${ }^{9}$ As an indicator of job instability, we consider yearly job-to-job transitions. A complete measure of worker flows (at a yearly frequency) can be obtained

\footnotetext{
${ }^{7}$ From 1968 to 2002, the households included in the LFS sample were interviewed in March of three consecutive years with one-third of the households replaced each year. Since 2003, the households included in the French LFS are interviewed six consecutive quarters with one-sixth of the households replaced each quarter. To avoid the break in series, we stop the analysis in 2002. This covers the main period of diffusion of the PC.

${ }^{8}$ Transitions toward retirement are not included: the minimum retirement age is 65 until 1982, and 60 afterwards.

${ }^{9}$ Nonetheless, this might overstate job insecurity as it also includes, for instance, women who stop working to raise their children. Restricting job insecurity to transitions toward unemployment yields qualitatively similar results.
} 
by adding the job-to-job and the employment-to-non-employment transition rates. In addition to the raw transition rates, we compute adjusted transition rates as follows. We run an ordinary least-squares (OLS) regression at the individual level of the outcome variable on whether the worker is a female, on his/her age (five-year age groups), on his/her tenure in firms, on his/her education group (six categories), the industry he/she is working in (16 industries), and the plant size (five dummies), from which we retrieve the residuals. These adjusted measures of the outcome of interest are then averaged by city $\times$ period cells; these can be interpreted as transition rates for a reference worker. These adjusted transition rates are the ones used in the regression analyses and part of the graphs.

In contrast to the persistent debate in the US (see Stevens, 2005; Farber, 2007, 2010), there is little doubt on the existence of a long-term trend in rising job insecurity in France (see Givord and Maurin, 2004). In our data, (raw) transitions from employment to unemployment and from employment to non-employment appear to rise significantly over the period, despite pauses in years of economic expansion (late 1980s, late 1990s) (see Figure A3 in the Online Appendix). On average, rates of transition from employment to unemployment appear to increase by more than $2 \mathrm{pp}$ for high-school dropouts and by about $1.5 \mathrm{pp}$ for high-school graduates between 1975 and 2002. This roughly corresponds to a multiplication by a factor of 1.5 or 2. In contrast, job-to-job transitions display no clear trend, and are strongly pro-cyclical. Overall, the strong increase in job insecurity motivates investigating digging further the potential explanatory role of IT adoption.

Lastly, we use the LFS data to compute occupation shares at the city level, in order to check whether IT adoption is associated with a shift towards higher occupations, as implied by the literature on skill-biased technical changes. We distinguish four occupational groups: managers and professionals; technicians and supervisors; clerks; blue-collar workers. For regression analyses, we compute adjusted shares in the same way as for transition rates. For instance, the adjusted share of managers and professionals can be interpreted as the probability that a reference worker (in terms of gender, age, education, tenure, firm size, and sector) in city $c$ is a manager.

Table A1 displays summary statistics for the main variables. This confirms the increase in job insecurity (transitions to non-employment) for high-school dropouts and high-school graduates, but also shows substantial variations across cities (large standard deviations). The share of blue-collar workers has decreased over the period, while other occupational groups have increased their share. Again, there are large differences across cities.

We now turn to graphical evidence on the link between skilled labour endowment and the adoption of IT. To do so, we split the 348 cities into 
four quartiles in terms of $E d u c_{c 0} .{ }^{10} \mathrm{Q} 4$ corresponds to the quartile with the highest skilled labour endowment, and Q1 to the quartile with the lowest. We then compute usage rate within each quartile, in various years. ${ }^{11,12}$ As shown by Figures 2(a) and 2(b), there is a clear correlation between $E d u c_{c 0}$, the initial endowment of skilled labour, and the adoption of computers and the Internet. This correlation holds even after controlling for the worker's education by looking separately at high-school dropouts and high-school graduates. Interestingly, differences in usage rates are higher for dropouts than for graduates, in absolute as well as in relative terms. In 1993, for instance, the probability that a high-school dropout located in a city with a low endowment in educated labour (first quartile) uses a PC at work is only 10 percent. It is almost 15 pp higher for a high-school dropout located in a well-endowed city (fourth quartile). The same difference is closer to $10 \mathrm{pp}$ for high-school graduates, on a basis of 40 percent. This first pass at the data seems to confirm the hypothesis that the local supply in educated labour might be a driver of IT adoption (even after controlling for the individual worker's education).

Are these systematic differences in the diffusion of IT paralleled by systematic differences in the evolution of job instability and its components? Figures 3-5 display graphical evidence. In each figure, the top two graphs display transition probabilities, comparing cities in the upper or lower half of the initial skill endowment $\left(E d u c_{c 0}\right)$. The bottom two graphs display the gap in transition probabilities for cities in the lower half of the initial skill endowment, adjusting for the individual worker characteristics mentioned above. ${ }^{13}$ Figure 3 considers all separations (i.e., the probability that a given worker is not in the same firm the next year). We focus on the bottom graphs, which control for differential evolutions due to changes in the composition of the two comparison groups. Patterns for high-school graduates are fairly similar in the two groups of cities. For high-school dropouts, the graphs suggest a slight relative decrease in their transition rate in more educated cities. Figure 4 considers transitions to non-employment as a

\footnotetext{
${ }^{10}$ Local labour markets are weighted by the size of their working-age population, as of 1975 .

${ }^{11}$ The French LFS is a clustered sample, so that some local labour markets are present in some years, and not in the others. Regression analysis in the next section will control for possible composition effects due to local labour markets entering and exiting the sample.

${ }^{12}$ Unfortunately, because of the break in the LFS between 2002 and 2003, we were not able to retrieve data by local labour markets in 2005 . Therefore, we only have one data point (1998) for the use of the Internet.

${ }^{13}$ We estimate a linear probability model on these controls plus a dummy for cities with initial skill endowment above median, separately for each year. We use the estimated coefficient on that dummy to predict the gap between cities with low or high initial skill endowment. The impact of the controls varies year by year, because the estimated coefficients on the control might differ, but also because of changing composition differences between the two comparison groups, due to the French LFS sampling frame.
} 
(a)
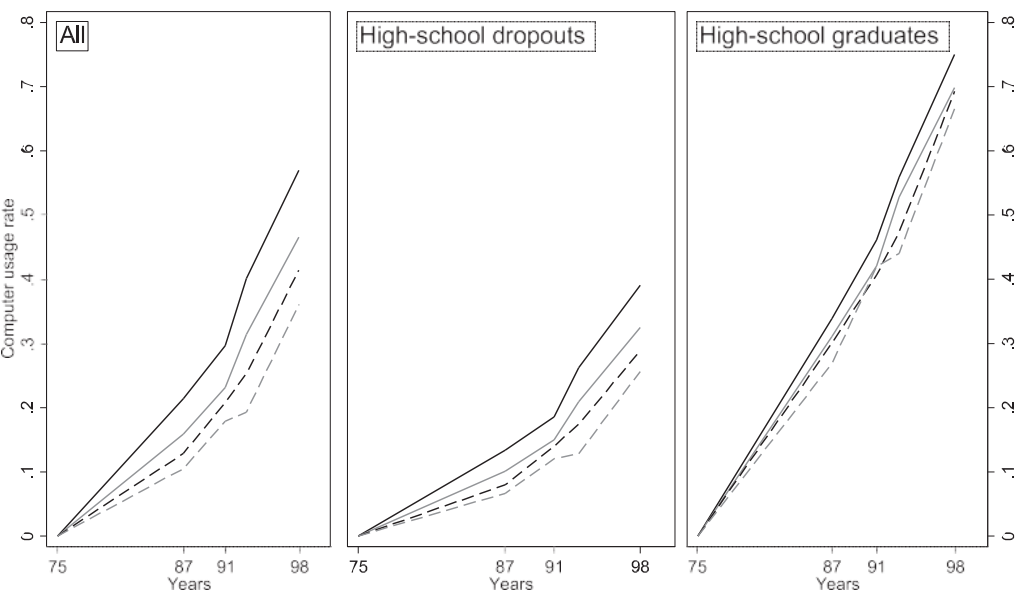

(b)
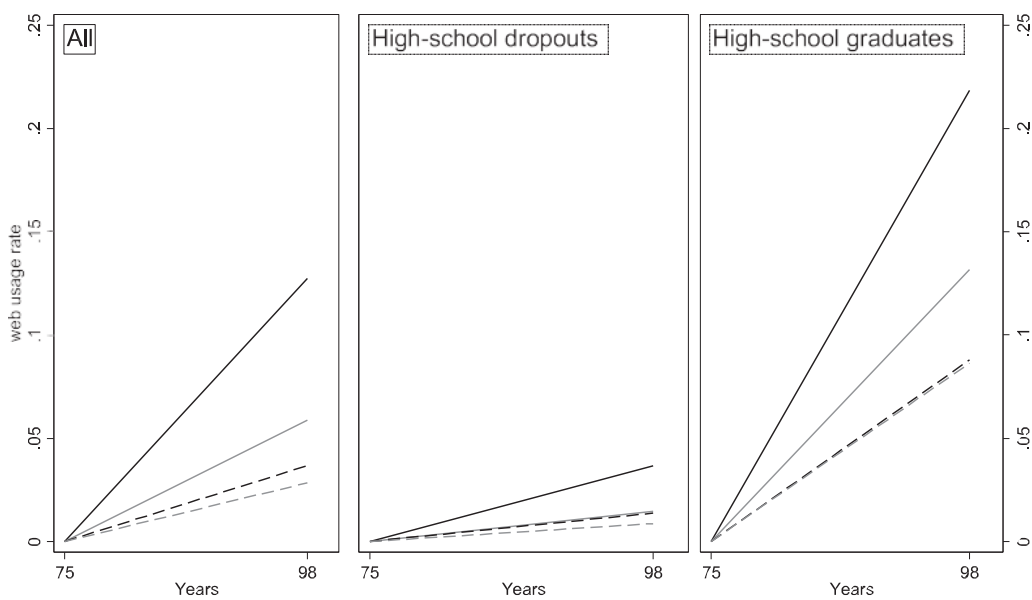

Q4 (highest initial skill endowment

Q3

Q1 (lowest initial Q2 skill endowment)

Fig. 2. (a) PC adoption and (b) Internet adoption by initial skill endowment

Sources: Working Conditions survey (1998), 1975 Population census.

Notes: PC and Internet usage rates, by quartiles of city initial endowment in skilled labour (share of workers with a high-school degree and above). 
(a)
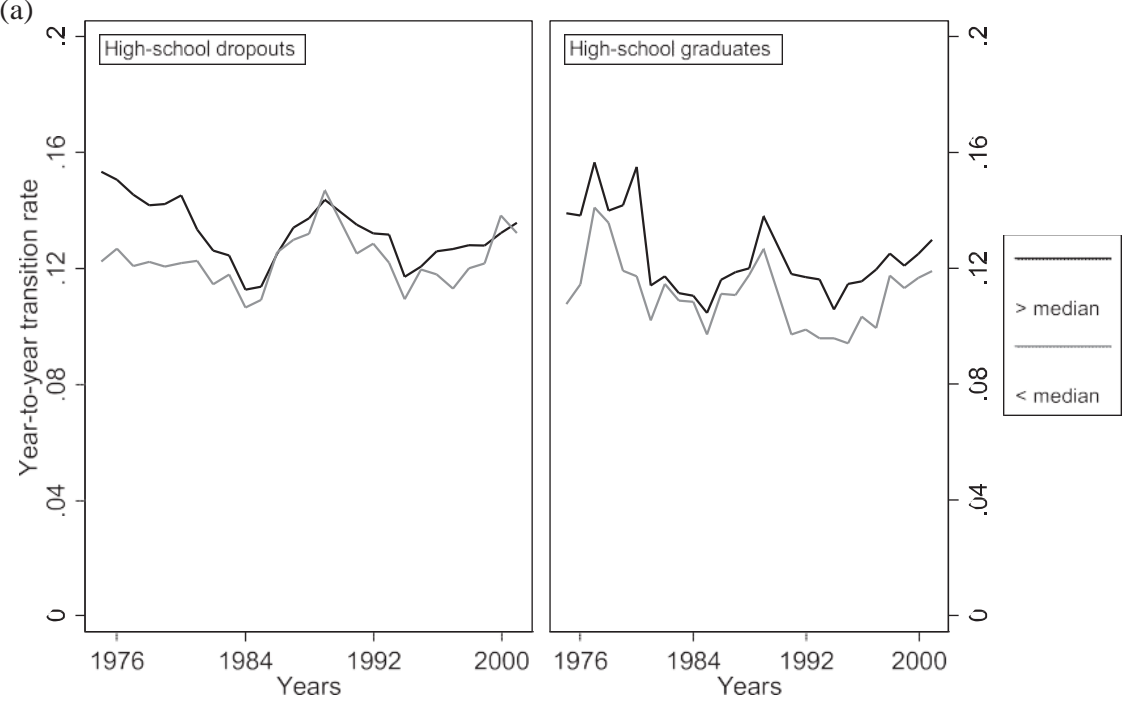

(b)
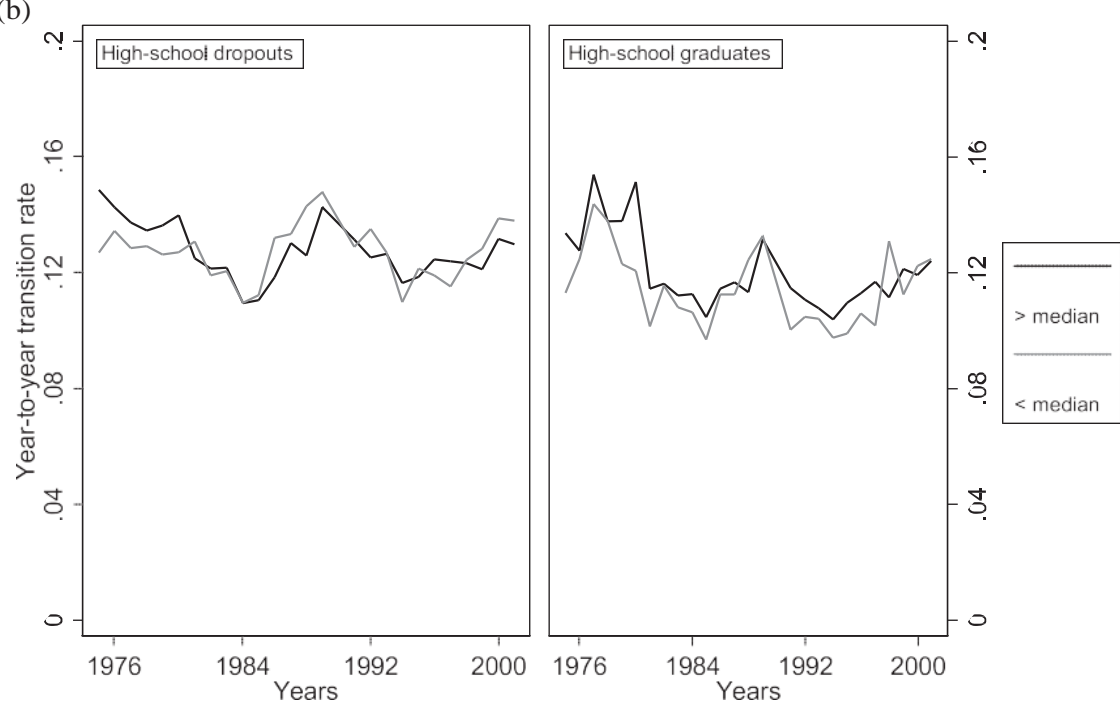

Fig. 3. Job instability by initial skilled labour endowment: (a) without controls; (b) with controls

Notes: Year-to-year transition rates from a firm to non-employment or to a new firm, computed separately for high-school dropouts and high-school graduates. Local labour markets are split into two groups depending on their initial skill endowment. In the plots of (b), the differences between cities with lower and higher initial skill mixes are net of differences in composition in terms of workers' gender, age (five-year groups), education group, years of tenure, sector (16 industries), plant size (five dummies), similar to the adjusted transition rates used in the regressions. 
(a)

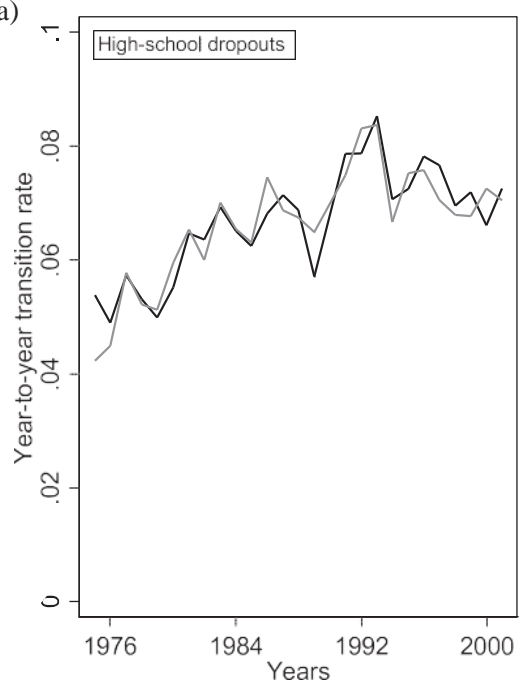

(b)

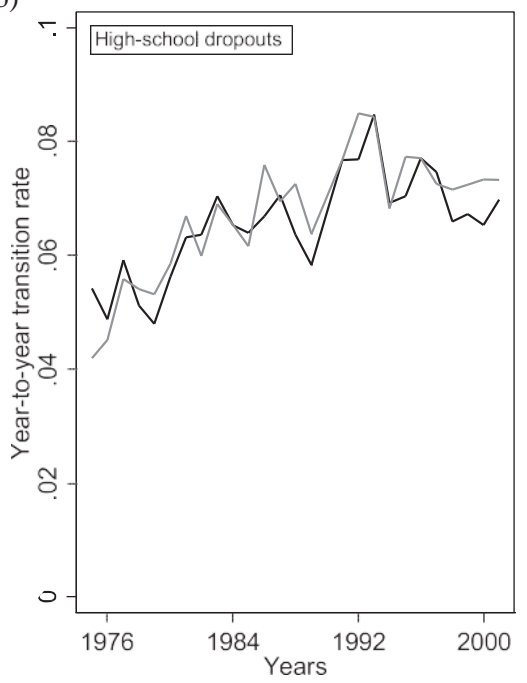

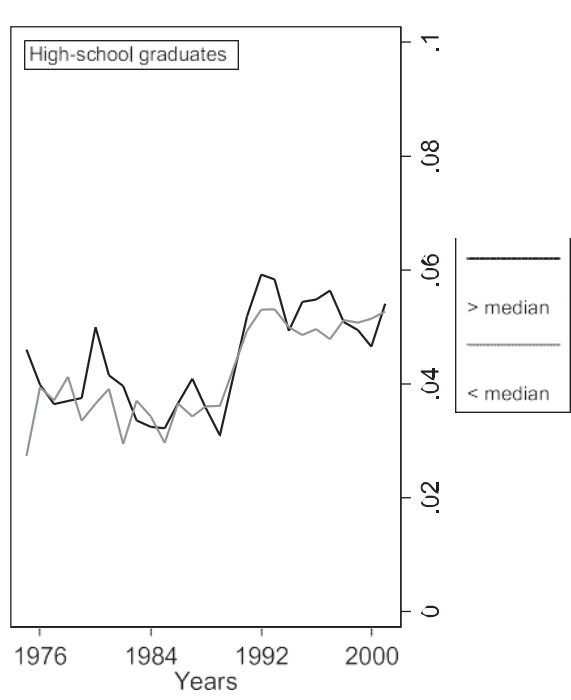

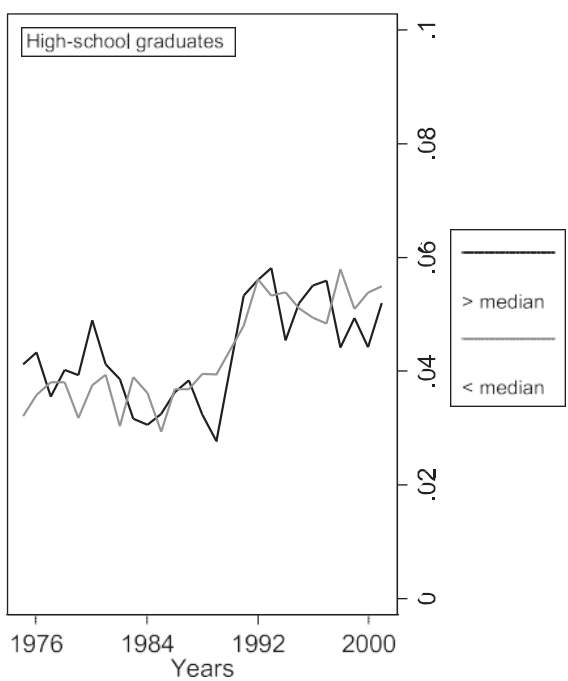

Fig. 4. Transitions from employment to non-employment, by initial skilled labour endowment: (a) without controls; (b) with controls

Notes: Year-to-year transition rates from employment to non-employment, computed separately for high-school dropouts and high-school graduates. Local labour markets are split into two groups depending on their initial skill endowment. In the plots of (b), the differences between cities with lower and higher initial skill mixes are net of differences in composition in terms of workers' gender, age (five-year groups), education group, years of tenure, sector (16 industries), plant size (five dummies), similar to the adjusted transition rates used in the regressions. 
(a)
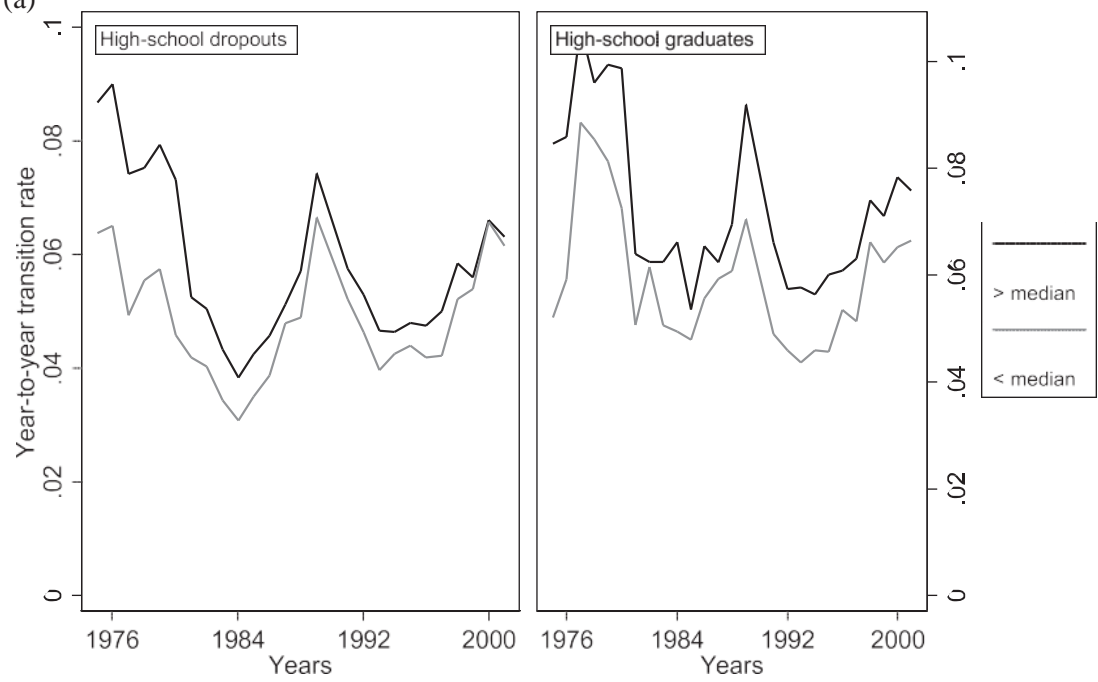

(b)
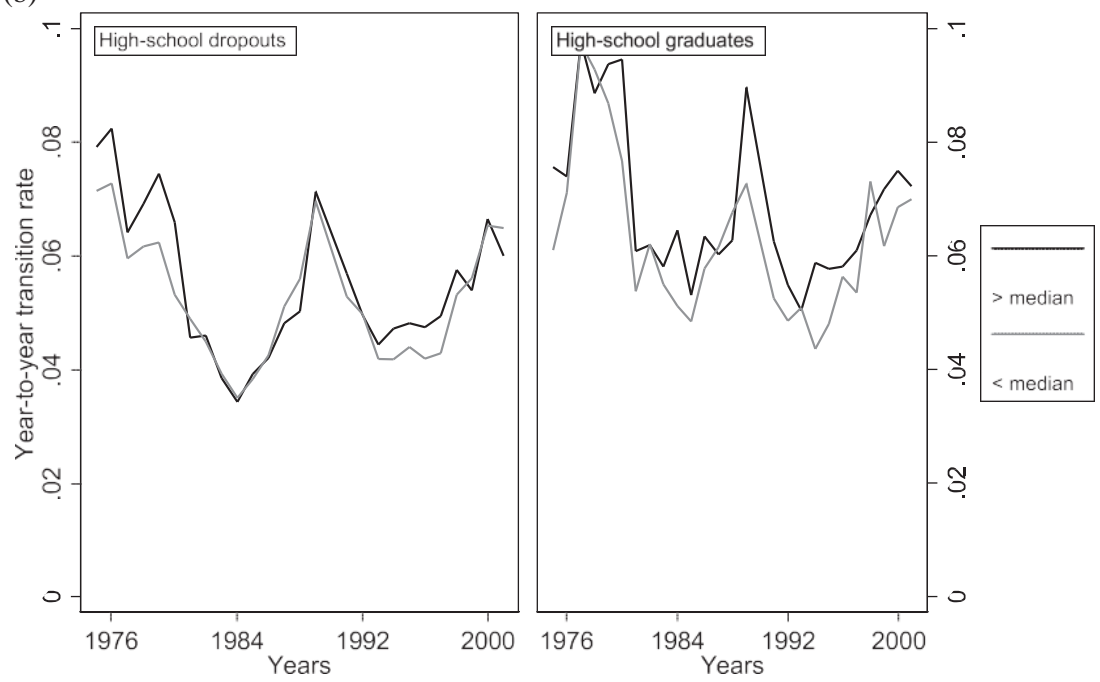

Fig. 5. Job-to-job transitions by initial skilled labour endowment: (a) without controls; (b) with controls

Notes: Year-to-year job-to-job transition rates, computed separately for high-school dropouts and high-school graduates. Local labour markets are split into two groups depending on their initial skill endowment. In the plots of (b), the differences between cities with lower and higher initial skill mixes are net of differences in composition in terms of workers' gender, age (five-year groups), education group, years of tenure, sector (16 industries), plant size (five dummies), similar to the adjusted transition rates used in the regressions. 
first component of total job instability. There is no clear difference in the trends for high-school graduates. For high-school dropouts, starting in the mid-1980s, transitions to non-employment tend to become less frequent in cities with a higher initial skill endowment (bottom-left graph). If we attribute this difference to the more rapid diffusion of IT, it would imply that IT has reduced transitions to non-employment for high-school dropouts. ${ }^{14}$ Job-to-job transitions are highly pro-cyclical (Figure 5). However, the evolutions are remarkably parallel across cities, for high-school graduates as well as dropouts.

The graphical analysis can be used to assess the validity of the parallel trend assumption: if one believes that there were no differences in technology adoption before, say, the mid-1980s, our identifying assumption implies that the trends in job-to-job transitions and in job insecurity should be parallel between 1975 and 1984. This holds for employment-to-nonemployment transitions. Transition rates diverge for high-school dropouts after 1985, but they are parallel before that date. It also holds for job-tojob transitions among high-school graduates. The only exception concerns job-to-job transitions among high-school dropouts, which tend to decline more in cities with higher initial skill endowment before 1985. Results for that indicator and skill group should therefore be taken with caution. ${ }^{15}$ However, the parallel trends observed for transitions to non-employment and for job-to-job transitions in the higher skill group before 1985 give credence to the identification strategy.

Overall, the graphical analysis confirms that the adoption of IT is predicted by the initial supply of skilled labour. However, there is no evidence that the diffusion of IT results in less stable employment relationships. If anything, patterns for transitions to non-employment suggest that the adoption of new technologies has been associated with less job insecurity for high-school dropouts.

\section{Impact of IT Diffusion on Job Instability: City-Level Evidence}

The first-stage equation measures the impact of skilled labour endowment at the city level on the diffusion of IT:

$$
\Delta I T_{c}=\beta_{0}+\beta_{1} E d u c_{c 0}+\beta_{2} A_{c}+\beta_{3} X_{c}+\beta_{4} \Delta X_{c}+\varepsilon_{c}
$$

where $I T_{c}$ is a measure of IT use (PC or Internet usage rate) in city $c, E d u c_{c 0}$ is the initial supply of skilled labour (the share of high-school

\footnotetext{
${ }^{14}$ Figure A4 in the Online Appendix displays qualitatively similar results using transition rates from employment to unemployment as a measure of job insecurity.

${ }^{15}$ It is, of course, also possible that IT was already diffusing before 1985 , which might explain why the trends in job-to-job transitions were not parallel at that time.
} 
graduates in 1975), and $A_{c}$ and $X_{c}$ are city characteristics. $\Delta$ denotes long differences, as we consider changes between the late 1970s and the late 1990s. In the case of IT use, however, we do not have measures in the late 1970s: considering the fact that PC usage at the workplace (and a fortiori Internet usage) was null or negligible at that time, we take usage rates in 1998 as a measure of $\Delta I T_{c}$.

Then, the structural equation of interest is

$$
\Delta T_{c}^{e}=Y_{0}{ }^{e}+Y_{1}{ }^{e} \Delta I T_{c}+Y_{2}{ }^{e} A_{c}+Y_{3}{ }^{e} X_{c}+Y_{4}{ }^{e} \Delta X_{c}+m_{c}{ }^{e},
$$

where $T_{c}{ }^{e}$ are adjusted city-level transition rates (see above), and $e$ indexes the occupation group. Given the evidence that IT-based technical change is biased against unskilled labour, we distinguish impacts on high-school graduates (or more educated workers) and high-school dropouts. Furthermore, following the literature, we distinguish two types of job instability: job insecurity (proxied by transitions from employment to non-employment ${ }^{16}$ ) and job-to-job transitions. This distinction is made because increases in the outside option of the worker could generate job-to-job transitions, while increases in the outside option of the firm generate job insecurity. However, changes in the match productivity might induce job-to-job transitions as well as transitions to non-employment.

As noted above, the parameter of interest $Y_{1}^{e}$ combines several effects that can take place at the workplace, at the firm, or at the city level. The goal of the econometric analysis is to evaluate the aggregate impact (i.e., the different mechanisms will not be identified separately). We estimate $v e$ by two-stage least-squares (2SLS) using $E d u c_{c 0}$ as an instrument. The exclusion restriction $E\left(m_{c}^{e} E d u c_{c 0}\right)=0$ implies that the initial skill endowment affects job instability only through its effect on the diffusion of IT, conditional on the control variables. We include city-level controls for the initial age composition of the workforce $\left(A_{c}\right)$ and for the sector composition $\left(X_{c}\right)(1975-1981)$, as well as changes in the sector composition $\left(\Delta X_{c}\right)$ between 1975-1981 and 1995-2001. Table A1 reports descriptive statistics for the different variables.

The instrumental variable (IV) strategy solves some of the problems of a direct estimation of equation (2) by OLS; for instance, any idiosyncratic shock that affects a given city (i.e., a positive demand shock on the market for goods) is likely to affect the ability of firms to invest in IT and to retain their workforce. This creates a bias in the OLS estimate, but not on the IV as long as demand shocks are evenly distributed across initially more or less educated cities. Clearly, however, the IV estimates are not above criticism. They might be biased if the differences in initial skill endowment generate differences in factors (other than IT) that affect job instability. We would

\footnotetext{
${ }^{16}$ Transitions from employment to unemployment yield qualitatively similar results.
} 
wrongly attribute these effects to IT. In particular, Acemoglu (1999) implies that unemployment increases with the share of skilled labour because it increases the demand for skills, leading firms to differentiate jobs for skilled and jobs for unskilled workers. If job instability and unemployment are related, this might imply that the current skill endowment is related to job instability (for reasons other than IT diffusion). However, if we assume that this additional relationship between skill endowment and job stability is stable over time, then it implies that only changes in skill endowment affect the changes in job stability analysed in equation (2). In that case, we can control for this confounding channel by adding changes in the city skill endowment to the control variables, while still using the initial skill endowment as an instrument for IT diffusion. Another potential confounding factor is related to the finding by Mazzolari and Ragusa (2013) that the demand for low-skill workers increases in highly educated cities through a rising demand for services. As such, the development of the service sector could create a negative relationship between initial skill endowment and the evolution of job instability for low-skill workers. This would create a bias in our IV estimates if this effect was not controlled for. Controls for six sector dummies and the adjustment of transition rates for the occupation group and for plant size should capture the effect of the expansion of services. More generally, the assumed exclusion restriction is consistent with models where the skill endowment affects local labour market outcomes outside of IT effects as long as the additional effects are constant over time (in which case controlling for changes in the skill endowment is enough) or go through changes in the composition of the workforce or in the industry mix, which we control for. However, in general, the assumed exclusion restriction is not consistent with models that imply unobservable and time-varying impacts of the local labour market skill endowment; we acknowledge this as a limitation of the approach.

Table 1 provides the first-stage estimates and confirms the graphical evidence: IT adoption significantly increases with the initial endowment in educated labour. The instrument is not weak. The $F$-statistics is 16.71, which is larger than the standard requirement of 10 (Column 3). More precisely, an increase in the skill endowment in 1975 from the first to the ninth decile increases the PC usage rate by about $10 \mathrm{pp}$.

Table 2 displays reduced-form evidence of the impact of the city initial skill endowment on job instability overall and on its two components. ${ }^{17}$ Although workers in more educated cities adopt IT faster, they do not

\footnotetext{
${ }^{17}$ We use data at the city level. More precisely, one observation corresponds to the change in the measure of job instability in a given city between its average in the late 1970s and its average in the late 1990s. The number of observations is lower than the total number of cities in France. This is due to the LFS sampling scheme.
} 
Table 1. Initial skill endowment and computer use in 1998 (first-stage equation, city-level data)

\begin{tabular}{lccc}
\hline & \multicolumn{3}{c}{ Computer use in 1998} \\
\cline { 2 - 4 } & $(1)$ & $(2)$ & $(3)$ \\
\hline Skill endowment in 1975 & $1.511^{* * *}$ & $1.302^{* * *}$ & $0.987^{* * *}$ \\
& $(0.159)$ & $(0.187)$ & $(0.241)$ \\
F-statistic & 89.81 & 48.37 & 16.71 \\
Number of observations (cities) & 269 & 269 & 269 \\
Controls for initial composition & No & Yes & Yes \\
Controls for composition changes & No & No & Yes
\end{tabular}

Sources: Population census (1975), LFS (1975-1981), and Working Conditions survey (1998).

Notes: The sample consists of individuals aged 20 to 59. Each column displays results from a separate OLS regression (first stage of Table 3). The dependent variables are PC usage rates among workers, computed from the 1998 Working Conditions survey. The independent variable (instrument) is the share of workers of highschool graduates and above, as measured by the 1975 population census. City-level observations are weighted by the total number of workers in the 1975-1981 waves of the LFS. Column 1 has no controls. Column 2 controls for the initial sector and age composition of the city (six sector dummies, and share of workers aged 40 and above, as measured in the 1975-1981 waves of the LFS). In addition, Column 3 controls for changes in the sector composition of the city (six categories) between 1975-1981 and 1995-2001 (see description of the controls in Table A1 of the Appendix). Standard errors (robust to heteroscedasticity) in parentheses. $* * *$, $* *$, and $*$ denote significance at the 1,5 , and 10 percent levels, respectively.

experience any increase in job instability. More specifically, our estimates are negative, which suggests that, if anything, the adoption of IT tends to reduce job instability. This decrease in job instability is particularly significant for high-school dropouts. Controlling for changes in the sector composition affects the results, suggesting that mechanisms such as the one suggested by Mazzolari and Ragusa (2013) might be at play. With the complete set of controls, a $10 \mathrm{pp}$ increase in high-school graduates in 1975 reduces subsequent change in job instability by $1 \mathrm{pp}$. This effect corresponds to a decrease in transitions to non-employment (1.1 pp). The initial skill endowment does not affect job-to-job transitions ( $0.05 \mathrm{pp})$. For high-school graduates, the corresponding estimates are also negative but smaller and insignificant. A $10 \mathrm{pp}$ increase in PC usage rate reduces job instability by $0.26 \mathrm{pp}$ in total. It is worth noting, however, that these differences between high-school graduates and high-school dropouts are not statistically significant.

Table 3 displays the corresponding 2SLS estimates, which are very close to the reduced-form estimates, not surprisingly given the first-stage results. Conditional on the controls, 2SLS estimates can be given a causal interpretation insofar as without IT diffusion, cities with different initial skill endowment would have displayed similar trends in job instability. All in all, we find no evidence that the diffusion of IT increases job-to-job transitions, and we find that it tends to reduce transitions to non-employment for high-school dropouts. 
Table 2. Impact of initial skill endowment on job instability (reduced-form estimates)

\begin{tabular}{|c|c|c|c|c|c|c|}
\hline & \multicolumn{3}{|c|}{ High-school dropouts } & \multicolumn{3}{|c|}{ High-school graduates } \\
\hline & (1) & (2) & (3) & (4) & (5) & (6) \\
\hline \multicolumn{7}{|c|}{ Panel A: job instability (all transitions) } \\
\hline Skill endowment in 1975 & $\begin{array}{c}-0.105^{* * *} \\
(0.033)\end{array}$ & $\begin{array}{l}-0.074 * \\
(0.043)\end{array}$ & $\begin{array}{l}* 0.103^{* *} \\
(0.050)\end{array}$ & $\begin{array}{l}-0.060^{*} \\
(0.032)\end{array}$ & $\begin{array}{l}* 0.075^{*} \\
(0.042)\end{array}$ & $\begin{array}{c}-0.026 \\
(0.070)\end{array}$ \\
\hline \multicolumn{7}{|c|}{ Panel B: transitions to non-employment } \\
\hline Skill endowment in 1975 & $\begin{array}{c}-0.013 \\
(0.025)\end{array}$ & $\begin{array}{c}-0.039 \\
(0.035)\end{array}$ & $\begin{array}{c}-0.108^{* * *} \\
(0.037)\end{array}$ & $\begin{array}{c}-0.014 \\
(0.021)\end{array}$ & $\begin{array}{c}-0.063^{* *} \\
(0.026)\end{array}$ & $\begin{array}{r}-0.041 \\
(0.044)\end{array}$ \\
\hline \multicolumn{7}{|l|}{ Panel C: job-to-job transitions } \\
\hline Skill endowment in 1975 & $\begin{array}{c}-0.092^{* * *} \\
(0.016)\end{array}$ & $\begin{array}{c}-0.035 \\
(0.028)\end{array}$ & $\begin{array}{c}0.005 \\
(0.036)\end{array}$ & $\begin{array}{c}-0.045^{*} \\
(0.024)\end{array}$ & $\begin{array}{c}-0.013 \\
(0.035)\end{array}$ & $\begin{array}{c}0.015 \\
(0.058)\end{array}$ \\
\hline No. of observations (cities) & 269 & 269 & 269 & 268 & 268 & 268 \\
\hline Controls for initial composition & No & Yes & Yes & No & Yes & Yes \\
\hline Controls for composition changes & No & No & Yes & No & No & Yes \\
\hline
\end{tabular}

Sources: Population census (1975), LFS (1975-1981, 1995-2001).

Notes: The sample consists of individuals aged 20 to 59. A $10 \mathrm{pp}$ increase in the share of high-school graduates at the city level in 1975 is associated with a 1 pp decrease in the job instability of high-school dropouts. The coefficient is statistically significant at the 5 percent level (third column). Each cell displays results from a separate OLS regression. The dependent variables are changes in the adjusted city-level transition rates between the late 1970s and the late 1990s (1975-1981 and 1995-2001). The independent variable (instrument) is the share of workers who have at least graduated from high school, measured in the 1975 population census. Citylevel observations are weighted by the total number of workers in the 1975-1981 waves of the LFS. Columns 1 and 4 have no controls. Columns 2 and 5 control for the initial sector composition (six categories) and the share of workers aged 40 and above, measured in the 1975-1981 waves of the LFS. In addition, Columns 3 and 6 control for changes in the sector composition of the city (six categories) between 1975-1981 and 1995-2001 (see description of the controls in Table A1 of the Appendix). Adjusted city-level transition rates are computed in a preliminary step: we regress transition indicators - whether an individual employed worker moved to non-employment (Panel B), to another job (Panel C), or to either of the two (Panel A) by the next year - on a set of individual characteristics, and take the average of the residuals across city $\times$ period cells. The individual characteristics are: whether the worker is a female, his/her age (five-year age groups), his/her tenure in firms, his/her education group (six categories), the industry he/she is initially working in (16 industries), and the plant size (five dummies). Standard errors (robust to heteroscedasticity) are given in parentheses. $* * *$, $* *$, and $*$ denote significance at the 1,5 , and 10 percent levels, respectively.

These results suggest that productivity gains associated with the development of IT compensate for the induced loss in specific human capital that could increase worker flows. A complementary explanation could be that firms adapt to the new skill requirements by upgrading the skills of their existing workforce through training instead of resorting to drawing from the external labour market. This investment in training could be especially relevant for individuals with low qualifications, thus explaining that IT diffusion particularly reduces the transitions of high-school dropouts. This scenario would imply that the investment in IT coincides with both a decrease in job instability for high-school dropouts and an upgrade in the occupational structure of firms. 
Table 3. Impact of IT diffusion on job instability (2SLS estimates)

\begin{tabular}{|c|c|c|c|c|c|c|}
\hline & \multicolumn{3}{|c|}{ High-school dropouts } & \multicolumn{3}{|c|}{ High-school graduates } \\
\hline & (1) & (2) & (3) & (4) & (5) & (6) \\
\hline \multicolumn{7}{|c|}{ Panel A: job instability (all transitions) } \\
\hline PC usage rate in 1998 & $\begin{array}{c}-0.070^{* * *} \\
(0.018)\end{array}$ & $\begin{array}{l}-0.057^{* *} \\
(0.028)\end{array}$ & $\begin{array}{c}-0.104^{* *} \\
(0.050)\end{array}$ & $\begin{array}{c}-0.039^{*} \\
(0.022)\end{array}$ & $\begin{array}{c}* 0.058^{*} \\
(0.033)\end{array}$ & $\begin{array}{r}-0.026 \\
(0.072)\end{array}$ \\
\hline \multicolumn{7}{|c|}{ Panel B: transitions to non-employment } \\
\hline PC usage rate in 1998 & $\begin{array}{c}-0.009 \\
(0.016)\end{array}$ & $\begin{array}{c}-0.030 \\
(0.025)\end{array}$ & $\begin{array}{c}-0.109^{* * *} \\
(0.039)\end{array}$ & $\begin{array}{r}-0.009 \\
(0.014)\end{array}$ & $\begin{array}{c}-0.048^{* *} \\
(0.022)\end{array}$ & $\begin{array}{r}-0.042 \\
(0.047)\end{array}$ \\
\hline \multicolumn{7}{|l|}{ Panel C: job-to-job transitions } \\
\hline PC usage rate in 1998 & $\begin{array}{l}-0.061^{* * *} \\
(0.010)\end{array}$ & $\begin{array}{c}-0.027 \\
(0.020)\end{array}$ & $\begin{array}{c}0.005 \\
(0.036)\end{array}$ & $\begin{array}{c}-0.030^{*} \\
(0.015)\end{array}$ & $\begin{array}{r}-0.010 \\
(0.027)\end{array}$ & $\begin{array}{c}0.016 \\
(0.059)\end{array}$ \\
\hline No. of observations (cities) & 269 & 269 & 269 & 268 & 268 & 268 \\
\hline Controls for initial composition & No & Yes & Yes & No & Yes & Yes \\
\hline Controls for composition changes & No & No & Yes & No & No & Yes \\
\hline
\end{tabular}

Sources: Population census (1975), LFS (1975-1981, 1995-2001).

Notes: The sample consists of individuals aged 20 to 59. A $10 \mathrm{pp}$ increase in computer usage rate in the city in 1998 results in a 1 pp decrease in the job instability of high-school dropouts. The coefficient is statistically significant at the 5 percent level (third column). Each cell displays results from a separate 2SLS regression. The dependent variables are changes in the adjusted city-level transition rates between the late 1970s and the late 1990s (1975-1981 and 1995-2001). The endogenous regressor is the share of workers using a PC (measured from the 1998 Working Conditions survey). The instrument is the share of workers who have at least graduated from high school (measured from the 1975 population census). City-level observations are weighted by the total number of workers in the 1975-1981 waves of the LFS. Columns 1 and 4 have no controls. Columns 2 and 5 control for the initial sector composition (six categories) and the share of workers aged 40 and above, measured in the 1975-1981 waves of the LFS. In addition, Columns 3 and 6 control for changes in the sector composition of the city (six categories) between 1975-1981 and 1995-2001 (see description of the controls in Table A1 of the Appendix). Adjusted city-level transition rates are computed in a preliminary step: we regress transition indicators - whether an individual employed worker moved to non-employment (Panel B), to another job (Panel C), or to either of the two (Panel A) by the next year - on a set of individual characteristics, and take the average of the residuals across city $\times$ period cells. The individual characteristics are: whether the worker is female, his/her age (five-year age groups), his/her tenure in firms, his/her education group (six categories), the industry he/she is initially working in (16 industries), and the plant size (five dummies). Standard errors (robust to heteroscedasticity) are given in parentheses. $* * *, * *$, and $*$ denote significance at the 1,5 , and 10 percent levels, respectively.

Table 4 presents 2SLS results of the affect of IT adoption on the occupational structure at the city level. The share of managers and professionals increases significantly at the expense of lower occupations: a $10 \mathrm{pp}$ increase in PC usage rate at the city level is associated with a $2.9 \mathrm{pp}$ increase in the share of managers and professionals. This is accounted for by a $1.4 \mathrm{pp}$ decrease in the share of clerks, and a 2 pp decrease in the share of blue-collar workers. These findings are consistent with the literature and strengthen our previous result that IT adoption has not spurred job instability: IT adoption has real consequences, yet it does not affect job instability.

To sum up, we find that IT adoption is not associated with an increase in job instability. If anything, IT reduces job instability for high-school 
(1)

Panel A: managers and professionals

PC usage rate in 1998

$0.167^{* * *}$

$(0.032)$

$-0.004$

$(0.033)$

Panel C: clerks

PC usage rate in 1998

Panel D: blue-collar workers

PC usage rate in 1998

No. of observation (cities)

Controls for initial composition

Controls for composition changes
(2)

$\begin{array}{ccc}-0.143^{* * *} & -0.123^{* *} & -0.135^{*} \\ (0.028) & (0.048) & (0.081) \\ & & \\ -0.021 & -0.084 & -0.202^{* *} \\ (0.031) & (0.052) & (0.094) \\ 269 & 269 & 269 \\ \text { No } & \text { Yes } & \text { Yes } \\ \text { No } & \text { No } & \text { Yes }\end{array}$

Sources: Population census (1975), LFS (1975-1981, 1995-2001).

Notes: The sample consists of individuals aged 20 to 59. A 10 pp increase in PC usage rate at the city level is associated with a $2.9 \mathrm{pp}$ increase in the share of managers and professionals. The coefficient is statistically significant at the 1 percent level (third column). Each cell displays results from a separate 2SLS regression. The dependent variables are changes in occupation shares between the late 1970s and the late 1990s (19751981 and 1995-2001). The endogenous regressor is the share of workers using a PC (measured from the 1998 Working Conditions survey). The instrument is the share of workers who have at least graduated from high school (measured from the 1975 population census). City-level observations are weighted by the total number of workers in the 1975-1981 waves of the LFS. Column 1 has no controls. Column 2 controls for the initial sector composition (six categories) and the share of workers aged 40 and above, measured in the 1975-1981 waves of the LFS. In addition, Column 3 controls for changes in the sector composition of the city (six categories) between 1975-1981 and 1995-2001 (see description of the controls in Table A1 of the Appendix). Standard errors (robust to heteroscedasticity) are given in parentheses. $* * *, * *$, and $*$ denote significance at the 1,5 , and 10 percent levels, respectively.

dropouts. In addition, our results show an upgrade in the occupational structure at the city level. Taken together, this suggests that firms adopting IT might use internal labour market mechanisms, such as training and promotions to upgrade the skills of their workforce. ${ }^{18}$ Comparing the 2SLS with OLS estimates (Table 5), the results suggest that the OLS estimates tend to underestimate the decrease in job instability caused by the development of IT. In most cases, 2SLS estimates are more negative than their OLS counterparts. While differences between OLS and 2SLS are not

\footnotetext{
${ }^{18}$ Using the LFS, we cannot investigate firms' human resources strategies. Evidence using firm-level data suggests that in order to shift their occupational structure upwards, firms tend to increase the training for clerks and blue-collar workers. This is done by Behaghel et al. (2012) using OLS. Results using the initial city-level skill endowment as an instrument for firm-level IT adoption are available in Behaghel and Moschion (2012).
} 
Table 5. IT diffusion and job instability (OLS regressions)

\begin{tabular}{|c|c|c|c|c|c|c|}
\hline & \multicolumn{3}{|c|}{ High-school dropouts } & \multicolumn{3}{|c|}{ High-school graduates } \\
\hline & (1) & (2) & (3) & (4) & $(5)$ & (6) \\
\hline \multicolumn{7}{|c|}{ Panel A: job instability (all transitions) } \\
\hline PC usage rate in 1998 & $\begin{array}{r}-0.002 \\
(0.008)\end{array}$ & $\begin{array}{c}-0.017^{*} \\
(0.009)\end{array}$ & $\begin{array}{c}-0.017^{* *} \\
(0.008)\end{array}$ & $\begin{array}{l}0.036^{* * *} \\
(0.010)\end{array}$ & $\begin{array}{l}-0.003 \\
(0.010)\end{array}$ & $\begin{array}{r}-0.002 \\
(0.010)\end{array}$ \\
\hline \multicolumn{7}{|c|}{ Panel B: transitions to non-employment } \\
\hline PC usage rate in 1998 & $\begin{array}{c}-0.015^{* *} \\
(0.007)\end{array}$ & $\begin{array}{c}-0.022^{* *} \\
(0.009)\end{array}$ & $\begin{array}{l}-0.022^{* * *} \\
(0.008)\end{array}$ & $\begin{array}{r}-0.003 \\
(0.006)\end{array}$ & $\begin{array}{r}-0.013 \\
(0.008)\end{array}$ & $\begin{array}{r}-0.012 \\
(0.008)\end{array}$ \\
\hline $\begin{array}{l}\text { Panel C: job-to-job transitions } \\
\text { PC usage rate in } 1998\end{array}$ & $\begin{array}{l}0.013^{* *} \\
(0.005)\end{array}$ & $\begin{array}{c}0.005 \\
(0.005)\end{array}$ & $\begin{array}{c}0.005 \\
(0.005)\end{array}$ & $\begin{array}{l}0.039^{* * *} \\
(0.009)\end{array}$ & $\begin{array}{c}0.009 \\
(0.008)\end{array}$ & $\begin{array}{c}0.010 \\
(0.008)\end{array}$ \\
\hline No. of observation (cities) & 269 & 269 & 269 & 268 & 268 & 268 \\
\hline Controls for initial composition & No & Yes & Yes & No & Yes & Yes \\
\hline Controls for composition changes & No & No & Yes & No & No & Yes \\
\hline
\end{tabular}

Sources: Population census (1975), LFS (1975-1981, 1995-2001).

Notes: The sample consists of individuals aged 20 to 59 . A $10 \mathrm{pp}$ increase in PC usage rate at the city level is associated with a decrease in job instability for high-school dropouts by $0.17 \mathrm{pp}$. The coefficient is statistically significant at the 5 percent level (third column). Each cell displays results from a separate OLS regression. The dependent variables are changes in the adjusted city-level transition rates between the late 1970s and the late 1990s (1975-1981 and 1995-2001). The regressor of interest is the share of workers using a PC (measured from the 1998 Working Conditions survey). City-level observations are weighted by the total number of workers in the 1975-1981 waves of the LFS. Columns 1 and 4 have no controls. Columns 2 and 5 control for the initial sector composition (six categories) and the share of workers aged 40 and above, measured in the 1975-1981 waves of the LFS. In addition, Columns 3 and 6 control for changes in the sector composition of the city (six categories) between 1975-1981 and 1995-2001 (see description of the controls in Table A1 of the Appendix). Adjusted city-level transition rates are computed in a preliminary step: we regress transition indicators - whether an individual employed worker moved to non-employment (Panel B), to another job (Panel C), or to either of the two (Panel A) by the next year - on a set of individual characteristics, and take the average of the residuals across city $\times$ period cells. The individual characteristics are: whether the worker is female, his/her age (five-year age groups), his/her tenure in firms, his/her education group (six categories), the industry he/she is initially working in (16 industries), and the plant size (five dummies). Standard errors (robust to heteroscedasticity) are given in parentheses. $* * *, * *$, and $*$ denote significance at the 1,5 , and 10 percent levels, respectively.

significant for high-school graduates, they are significant in the case of job instability and job insecurity for high-school dropouts. This suggests that the OLS estimates are biased toward IT increasing job instability. This could reflect the fact that firms affected by adverse shocks (e.g., a negative demand shock) react by reducing their workforce, and simultaneously take advantage of the changes to introduce IT.

As noted above, the current local skill endowment can affect job instability through other channels than IT (e.g., through the type of jobs created by firms, as in Acemoglu, 1999). This implies a relationship between changes in skill endowment and changes in job instability that we can account for by adding changes in skill endowment between the late 1970s and the late 
1990s to the control variables. ${ }^{19}$ This is done in Table A2 (Columns 1 and 4). The correlation between changes in skill endowment and initial skill endowment implies that the strength of our instrument is reduced, so that standard errors on computer use increase, and effects become less significant. However, point estimates are close to those of Table 3. The results are thus relatively robust to unobservable channels through which the current skill endowment affects job instability.

We perform a variety of other robustness checks. Interestingly, all our results are qualitatively confirmed when the Internet is used as the IT measure instead of PC usage (Columns 2 and 5 of Table A2). This is consistent with PC usage and Internet usage being proxies for an underlying broader set of IT measures.

Defining skilled workers as those with a high-school or higher degree is somewhat at odds with the existing body of literature, which defines them as college-educated (or efficiency weighted measures). However, as of 1975, the college-educated are a tiny minority in the stock of French workers. Moreover, the fraction of college-educated workers and the fraction of workers with a high-school degree are very strongly correlated, so that alternative measures make little difference. Indeed, we check that results are robust to using the share of workers with some college education rather than the share of workers with a high-school degree or higher as our measure of the initial skill endowment (Columns 3 and 6 of Table A2).

\section{Conclusion}

Based on long-term differences across local labour markets, we find that workers and firms located in more educated labour markets tend to adopt IT faster. This is consistent with models of endogenous adoption of new technologies. However, workers do not experience less job stability. This is at odds with post-Fordist theories. Our findings also show that IT diffusion leads to an upgrading of the occupational structure. Taken together, these results suggest that firms' human resource strategies, in particular internal labour markets' mechanisms such as firm-provided training and internal promotions, might still play a large role, which is consistent with related evidence in Behaghel et al. (2012).

As noted in the introduction, the significant rise of job insecurity in France over the past decades makes it an interesting case to study. Of course, as with any study of a single country, an important question remains as to what extent our results can be generalized. In particular, France is characterized by strict employment protection legislation (Venn, 2009) and

\footnotetext{
${ }^{19}$ To do so, we need to assume that the relationship between skill endowment and job instability is stable over time.
} 
this might be one reason why internal labour markets have survived: firms would rely on internal adjustments because going to the external labour market would be too costly. A similar analysis on other countries with less stringent employment protections, such as the UK or US, would be an interesting avenue for further research. Nevertheless, until such analysis is conducted, the results obtained for France should not be dismissed as obviously idiosyncratic, for at least two reasons. First, the stringent employment protection in France has not prevented an overall increase in job insecurity over the period: this rise could have been concentrated on firms that adopted new technologies, but it was not. Second, cross-country analysis does not always support intuitive predictions on the effects of employment protection; for instance, recent evidence by Bassanini et al. (2007) suggests that the amount of training provided by firms would actually be negatively correlated to employment protection legislation. This deserves further research.

\section{Appendix}

Table A1. Descriptive statistics

\begin{tabular}{|c|c|c|c|c|c|c|}
\hline & \multicolumn{2}{|c|}{ All cities } & \multicolumn{2}{|c|}{$\begin{array}{l}\text { Share of HSG }> \\
\text { median }\end{array}$} & \multicolumn{2}{|c|}{$\begin{array}{l}\text { Share of HSF }< \\
\text { median }\end{array}$} \\
\hline & Mean & Std dev. & Mean & Std dev. & Mean & Std dev. \\
\hline \multicolumn{7}{|l|}{ Panel A: initial composition } \\
\hline Share of high-school graduates (1975) & 0.15 & 0.06 & 0.19 & 0.05 & 0.11 & 0.02 \\
\hline Share of college graduates (1975) & 0.08 & 0.04 & 0.11 & 0.04 & 0.05 & 0.01 \\
\hline Share above 40 years old (1975-1981) & 0.47 & 0.05 & 0.47 & 0.04 & 0.47 & 0.07 \\
\hline \multicolumn{7}{|l|}{ Sector composition (1975-1981): } \\
\hline Manufacturing & 0.28 & 0.11 & 0.25 & 0.08 & 0.32 & 0.13 \\
\hline Construction & 0.09 & 0.03 & 0.09 & 0.02 & 0.09 & 0.03 \\
\hline Retail and services to consumers & 0.19 & 0.05 & 0.21 & 0.04 & 0.17 & 0.05 \\
\hline Services to businesses & 0.13 & 0.06 & 0.16 & 0.06 & 0.10 & 0.05 \\
\hline $\begin{array}{l}\text { Health, education, community } \\
\text { work }\end{array}$ & 0.21 & 0.06 & 0.24 & 0.04 & 0.18 & 0.06 \\
\hline Agriculture & 0.09 & 0.10 & 0.04 & 0.05 & 0.14 & 0.13 \\
\hline \multicolumn{7}{|l|}{ Panel B: composition changes } \\
\hline \multicolumn{7}{|l|}{$\begin{array}{l}\text { Changes in sector composition (1995- } \\
2001 \text { vs. 1975-1981): }\end{array}$} \\
\hline Manufacturing & -0.09 & 0.08 & -0.09 & 0.06 & -0.09 & 0.10 \\
\hline Construction & -0.03 & 0.03 & -0.03 & 0.02 & -0.02 & 0.03 \\
\hline Retail and services to consumers & 0.01 & 0.04 & 0.00 & 0.03 & 0.02 & 0.05 \\
\hline Services to businesses & 0.07 & 0.04 & 0.08 & 0.03 & 0.06 & 0.04 \\
\hline $\begin{array}{l}\text { Health, education, community } \\
\text { work }\end{array}$ & 0.08 & 0.05 & 0.07 & 0.04 & 0.09 & 0.06 \\
\hline Agriculture & -0.04 & 0.08 & -0.02 & 0.04 & -0.06 & 0.10 \\
\hline
\end{tabular}




\begin{tabular}{|c|c|c|c|c|c|c|}
\hline & \multicolumn{2}{|c|}{ All cities } & \multicolumn{2}{|c|}{$\begin{array}{c}\text { Share of HSG > } \\
\text { median }\end{array}$} & \multicolumn{2}{|c|}{$\begin{array}{c}\text { Share of HSF }< \\
\text { median }\end{array}$} \\
\hline & Mean & Std dev. & Mean & Std dev. & Mean & Std dev. \\
\hline $\begin{array}{l}\text { Panel C: information technologies } \\
\text { Computer use (1998) }\end{array}$ & 0.46 & 0.14 & 0.52 & 0.11 & 0.38 & 0.13 \\
\hline \multicolumn{7}{|l|}{$\begin{array}{l}\text { Panel D: changes in job instability } \\
\text { Changes in yearly transition rates (1995- } \\
2001 \text { vs. 1975-1981): }\end{array}$} \\
\hline $\begin{array}{l}\text { Job instability HS dropouts } \\
\text { Transitions to non employment } \\
\text { HS dropouts }\end{array}$ & $\begin{array}{l}0.010 \\
0.018\end{array}$ & $\begin{array}{l}0.025 \\
0.018\end{array}$ & $\begin{array}{l}0.003 \\
0.019\end{array}$ & $\begin{array}{l}0.019 \\
0.013\end{array}$ & $\begin{array}{l}0.019 \\
0.017\end{array}$ & $\begin{array}{l}0.028 \\
0.023\end{array}$ \\
\hline Job-to-job transitions HS dropouts & -0.008 & 0.021 & -0.016 & 0.016 & 0.001 & 0.021 \\
\hline $\begin{array}{l}\text { Job instability HS graduates } \\
\text { Transitions to non employment } \\
\text { HS graduates }\end{array}$ & $\begin{array}{r}-0.005 \\
0.014\end{array}$ & $\begin{array}{l}0.045 \\
0.027\end{array}$ & $\begin{array}{r}-0.008 \\
0.013\end{array}$ & $\begin{array}{l}0.024 \\
0.015\end{array}$ & $\begin{array}{l}0.000 \\
0.014\end{array}$ & $\begin{array}{l}0.061 \\
0.037\end{array}$ \\
\hline Job-to-job transitions HS graduates & -0.018 & 0.033 & -0.021 & 0.022 & -0.015 & 0.043 \\
\hline \multicolumn{7}{|l|}{$\begin{array}{l}\text { Changes in share of occupations (1995- } \\
2001 \text { vs. 1975-1981): }\end{array}$} \\
\hline Managers and professionals & 0.052 & 0.060 & 0.078 & 0.060 & 0.022 & 0.043 \\
\hline Technicians and supervisors & 0.034 & 0.046 & 0.033 & 0.039 & 0.034 & 0.054 \\
\hline Clerks & 0.029 & 0.058 & 0.005 & 0.053 & 0.057 & 0.051 \\
\hline Blue-collar workers & -0.114 & 0.071 & -0.116 & 0.059 & -0.113 & 0.083 \\
\hline Number of cities & & 0 & & o & & 90 \\
\hline $\begin{array}{l}\text { Number of cities weighted by number } \\
\text { of observations in LFS }\end{array}$ & 319 & 807 & & 778 & 167 & 029 \\
\hline
\end{tabular}

Sources: Wage Survey and APEH database, 1993-2004.

Notes: Cities are weighted by the number of observations in the 1975-1981 waves of the LFS.

Table A2. Robustness checks to Table 3

\begin{tabular}{|c|c|c|c|c|c|c|}
\hline & \multicolumn{3}{|c|}{ High-school dropouts } & \multicolumn{3}{|c|}{ High-school graduates } \\
\hline & (1) & (2) & (3) & (4) & (5) & (6) \\
\hline \multicolumn{7}{|c|}{ Panel A: job instability (all transitions) } \\
\hline PC usage rate in 1998 & $\begin{array}{c}-0.095 \\
(0.076)\end{array}$ & & $\begin{array}{r}-0.089^{*} \\
(0.051)\end{array}$ & $\begin{array}{c}-0.177 \\
(0.132)\end{array}$ & & $\begin{array}{r}-0.011 \\
(0.072)\end{array}$ \\
\hline Internet usage rate in 1998 & & $\begin{array}{c}-0.096 \\
(0.061)\end{array}$ & & & $\begin{array}{c}-0.012 \\
(0.077)\end{array}$ & \\
\hline \multicolumn{7}{|c|}{ Panel B: transitions to non-employment } \\
\hline PC usage rate in 1998 & $\begin{array}{c}-0.067 \\
(0.053)\end{array}$ & & $\begin{array}{c}-0.098^{* *} \\
(0.040)\end{array}$ & $\begin{array}{r}-0.069 \\
(0.072)\end{array}$ & & $\begin{array}{r}-0.033 \\
(0.046)\end{array}$ \\
\hline Internet usage rate in 1998 & & $\begin{array}{c}-0.105^{* *} \\
(0.047)\end{array}$ & & & $\begin{array}{c}-0.035 \\
(0.049)\end{array}$ & \\
\hline \multicolumn{7}{|c|}{ Panel C: job-to-job transitions } \\
\hline PC usage rate in 1998 & $\begin{array}{c}-0.028 \\
(0.055)\end{array}$ & & $\begin{array}{c}0.008 \\
(0.038)\end{array}$ & $\begin{array}{r}-0.108 \\
(0.092)\end{array}$ & & $\begin{array}{c}0.022 \\
(0.061)\end{array}$ \\
\hline
\end{tabular}




\begin{tabular}{|c|c|c|c|c|c|c|}
\hline & \multicolumn{3}{|c|}{ High-school dropouts } & \multicolumn{3}{|c|}{ High-school graduates } \\
\hline & (1) & (2) & (3) & (4) & (5) & (6) \\
\hline Internet usage rate in 1998 & & $\begin{array}{c}0.009 \\
(0.041)\end{array}$ & & & $\begin{array}{c}0.023 \\
(0.065)\end{array}$ & \\
\hline No. of cities & 269 & 269 & 269 & 268 & 268 & 268 \\
\hline Controls for initial composition & Yes & Yes & Yes & Yes & Yes & Yes \\
\hline Controls for composition changes & Yes & Yes & Yes & Yes & Yes & Yes \\
\hline
\end{tabular}

Sources: Population census (1975), LFS (1975-1981, 1995-2001).

Notes: Robustness checks to Table 3. The sample consists of individuals aged 20 to 59. A 10 pp increase in computer usage rate in the city in 1998 results in a $0.89 \mathrm{pp}$ decrease in the job instability of high-school dropouts. This is close to the result in Table 3, but the coefficient is statistically significant at the 10 percent level only (third column). Each cell displays results from a separate 2SLS regression. The baseline specification corresponds to Columns 3 and 6 of Table 3. In addition, Columns 1 and 4 control for changes in the share of workers with a high-school degree and above, between 1975 and 1999. Columns 2 and 5 use Internet usage rate instead of PC usage rates. The instrument in Columns 3 and 6 is the share of workers with some college education (in 1975) rather than the share of workers with a high-school degree and above (in 1975). Standard errors (robust to heteroscedasticity) are given in parentheses. $* * *, * *$, and $*$ denote significance at the 1,5 , and 10 percent levels, respectively.

\section{References}

Acemoglu, D. (1999), Changes in Unemployment and Wage Inequality: An Alternative Theory and Some Evidence, American Economic Review 89 (5), 1259-1278.

Acemoglu, D. (2007), Equilibrium Bias of Technology, Econometrica 75, 1371-1410.

Bassanini, A., Booth, A., Brunello, G., De Paola, M., and Leuwen, E. (2007), Workplace Training in Europe, in G. Brunello, P. Garibaldi, and E. Wasmer (eds.), Education and Training in Europe, Oxford University Press, New York, 143-342.

Basu, S. and Weil, D. (1998), Appropriate Technology and Growth, Quarterly Journal of Economics 113, 1025-1054.

Bauer, T. and Bender, S. (2004), Technological Change, Organizational Change and Job Turnover, Labour Economics 11, 265-291.

Beaudry, P., Doms, M., and Lewis, E. (2010), Should the Personal Computer Be Considered a Technological Revolution? Evidence from U.S. Metropolitan Areas, Journal of Political Economy 118, 988-1036.

Behaghel, L. and Moschion, J. (2012), Skilled Labor Supply, IT-Based Technical Change and Job Instability, IZA Discussion Paper 6839.

Behaghel, L., Caroli, E., and Walkowiak, E. (2012), Information and Communication Technologies and Skill Upgrading: The Role of Internal vs. External Labour Markets, Oxford Economic Papers 64, 490-517.

Caroli, E. (2007), Internal versus External Labour Flexibility: The Role of Knowledge Codification, National Institute Economic Review 201, 107-118. 
Caselli, F. (1999), Technological Revolutions, American Economic Review 89 (1), 78-102.

Farber, H. (2007), Is the Company Man an Anachronism? Trends in Long Term Employment in the U.S., 1973-2006, in S. Danziger and C. Rouse (eds.), The Price of Independence, Russell Sage, New York.

Farber, H. (2010), Job Loss and the Decline in Job Security in the United States, in K. G. Abraham, J. R. Spletzer, and M. Harper (eds.), Labour in the New Economy, University of Chicago Press, Chicago, 223-262.

Givord, P. and Maurin, E. (2004), Changes in Job Security and their Causes: An Empirical Analysis for France, 1982-2002, European Economic Review 48, 595-615.

Goldin, C. and Sokoloff, K. (1984), The Relative Productivity Hypothesis of Industrialization: The American Case, 1820 to 1850, Quarterly Journal of Economics 99, 461-488.

Gottschalk, P. and Moffitt, R. (1999), Changes in Job Instability and Insecurity Using Monthly Survey Data, Journal of Labour Economics 17, Part 2, S91-S126.

Habakkuk, H. J. (1962), American and British Technology in the Nineteenth Century, Cambridge University Press, Cambridge.

Marsden, D. (1999), A Theory of Employment Systems: Micro-foundations of Social Diversity, Oxford University Press, Oxford.

Mazzolari, F. and Ragusa, G. (2013), Spillovers from High-Skill Consumption to Low-Skill Labour Markets, Review of Economics and Statistics 95, 74-86.

Mincer, J. (1989), Human Capital Responses to Technological Change in the Labour Market, NBER Working Paper 3207.

Moretti, E. (2004), Estimating the Social Return to Higher Education: Evidence from Longitudinal and Repeated Cross-Sectional Data, Journal of Econometrics 121, 175-212.

Neumark, D. and Reed, D. (2004), Employment Relationships in the New Economy, Labour Economics 11, 1-31.

Reich, M. (2001), The Future of Success, Alfred A. Knopf, New York.

Stevens, A. H. (2005), The More Things Change, the More they Stay the Same: Trends in Long-Term Employment in the United States, 1969-2002, NBER Working Paper 11878.

Venn, D. (2009), Legislation, Collective Bargaining and Enforcement: Updating the OECD Employment Protection Indicators, OECD-ELSA Working Paper.

Zeira, J. (1998), Workers, Machines and Economic Growth, Quarterly Journal of Economics $113,1091-1117$. 


\section{University Library}

\section{- M M I E R R V A gateway to Melbourne's research publications}

Minerva Access is the Institutional Repository of The University of Melbourne

Author/s:

Behaghel, L;Moschion, J

Title:

IT-Based Technical Change and Job Instability

Date:

2016-01-01

Citation:

Behaghel, L. \& Moschion, J. (2016). IT-Based Technical Change and Job Instability.

SCANDINAVIAN JOURNAL OF ECONOMICS, 118 (1), pp.79-104. https://doi.org/10.1111/ sjoe.12129.

Persistent Link:

http://hdl.handle.net/11343/124144 